ERIC DE SENA,

American Research Center in Sofia,

Sofia, Bulgaria

sofiadirector@arcsofia.org
UDC: 904:72”652”(498) ; 902.2(498)”2010”

Original research article

Received: April 05 2013

Accepted: October $15^{\text {th }} 2013$

\title{
POROLISSUM: A CASE STUDY IN THE ARCHAEOLOGICAL HERITAGE OF ROMANIA
}

\begin{abstract}
This paper presents an overview of the Roman site, Porolissum, located in northwestern Romania. The first section concerns the history of the site and an overview of its preserved features. The second section characterizes the stakeholders at Porolissum, the challenges and the activities of the stakeholders to confront the challenges. The conclusion suggests that the site can be better administered and promoted with the development of a clear vision, a business plan, better cooperation between the stakeholders and support from central authorities in Bucharest.
\end{abstract}

Keywords: Porolissum, Roman, Romania.

\section{INTRODUCTION.}

Located in northwestern Romania, the Roman city of Porolissum is one of the most important archaeological sites in the Balkans. Porolissum served as a crucial military center and developed into a small Roman city with trade connections between the empire and barbaricum. The author of this paper served as co-director of the Porolissum Forum Project together with Alexandru V. Matei 2004-10 and with Robert Wanner in 2011 and is, therefore, very familiar with the management and promotion of the site. This paper discusses the manner in which the site is administered, investigated and promoted by a variety of stakeholders.

\section{OVERVIEW OF THE ARCHAEOLOGI- CAL SITE OF POROLISSUM}

Established in AD 106 by Trajan, Porolissum was the northernmost military center of Roman Dacia and was a municipium by at least the early Severan period (Fig 1). It initially served as the primary military base in the hierarchy of the Roman defensive network in northern Dacia with secondary fortresses located at Tihău (Gudea 1985), Romita-Certiae (Matei and Bajusz 1997), Romanaşi (Tamba 1997) and Buciumi (Chirilă et al. 1972; Landes-Gyemant and Gudea 2001). The city is set upon the summit and slopes of Pomet Hill on the southern side of a mountain pass that allowed communication between the Transylvanian region of the Carpathian Mountains and the Pannonian Plains. In addition to protecting a ma- 


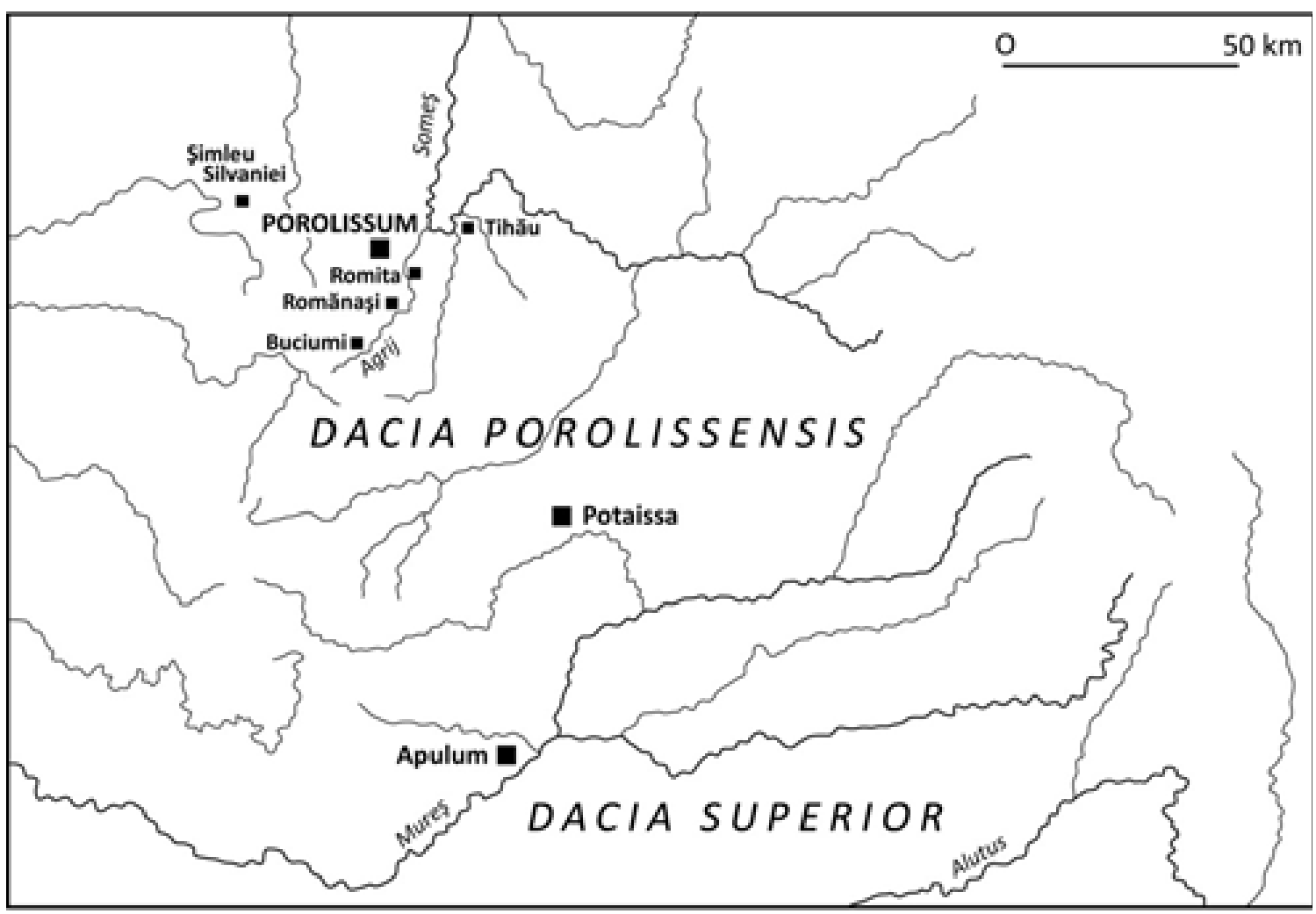

Fig. 1 Map indicating the location of Porolissum (E.C. De Sena and J.P. Ikäheimo)

jor corridor into northern Dacia, the location of Porolissum affords a commanding view of a 20 mile stretch of the Roman limes and offers a line of vision toward one of the most important native Dacian sites, Şimleu Silvaniei some 16 miles to the west (Pop et al., 2006), probably Dacidava mentioned by Claudius Ptolomeus (Geography III, Dacia).

The original Roman military center at Porolissum consisted of several thousand legionary and auxiliary soldiers (Petolescu 1997, 66-141; Gudea and Schüller 1998, 120; Matei 2003, 279281). During the earliest phase of occupation, the cohorts appear to have been grouped into a series of wooden fortresses on Pomet Hill and nearby Citera Hill (Matei 2003; Diaconescu 2004). Within a few decades, the soldiers were consolidated into the large stone fortress which still dominates Pomet Hill. This event may have coincided with Hadrian's reorganization of Dacia and the establishment of Porolissum as the capital of Dacia Porolissensis and was certainly no later than the construction of a stone amphitheater in AD 157 (C.I.L. 03, 00836; Bajusz 1997, 1999). By the time soldiers were consolidated into the stone fortress, a sizable vicus had developed on the eastern and southern slopes of Pomet Hill. The later second and early third centuries AD witnessed further political, demographic and urban developments. The city was renamed municipium Septimium Porolissensis during the reign of either Septimius Severus or Caracalla. It was also during the Severan period that the amphitheater and a pair of temples were renovated (Bajusz 1999; Gudea 1989, Gudea and Tamba 2001, 11-18); many of the structures excavated by the Porolissum Forum Project team were also rebuilt/renovated at this time.

The late Roman (AD 235-271) and immediate post-Roman (AD 271-375) periods of Porolissum are not fully understood. While there is a gap in the sequence of coins between ca. AD 262 and 325 (Găzdac 2006), there are no signs of destruction or rapid abandonment of the site (cf. Inomata and Webb 2003). Regardless of the process of the Romans' withdrawal, there is some evidence that Porolissum was inhabited at least sporadically over the course of the next century and that the inhabitants even maintained some commercial relations with the Romans until the late fourth century, attested by a small number of late Ro- 


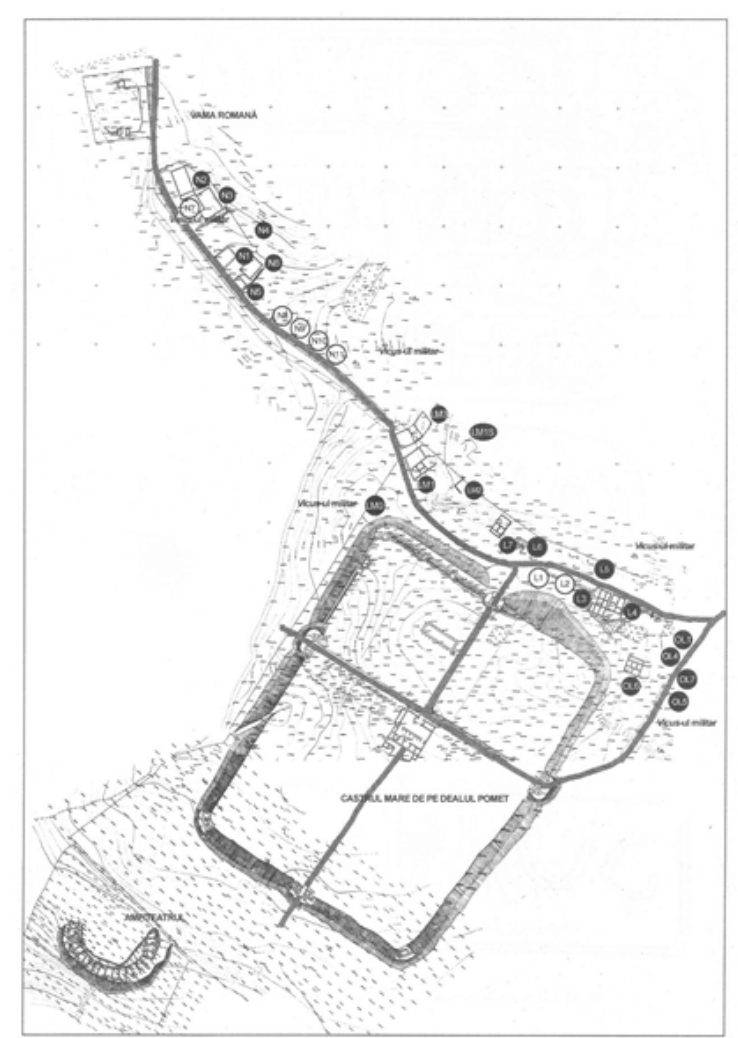

Fig. 2 Plan of excavated areas of Porolissum (Tamba 2009, fig 25)

man coins dating to $\mathrm{AD} 325-375$ (Găzdac 2006).

There is no evidence of land usage after the late 4th c. AD and the process of decay, spoliation and forestation led to the vanishing of the city. By the early modern period, the site had been forgotten and it was not until the 19th century, when a land baron had his peasants cut timber, that the site was re-discovered. Excavations through the mid 20th century were limited and focused primarily upon the fortress. Systematic excavations led by scholars from Cluj and Zalău only began in 1977.

While much of the ancient city remains to be excavated, archaeologists have revealed a $1 \mathrm{~km}$ stretch of Roman road as well as an adjacent sequence of houses, temples and commercial spaces (Fig. 2). The two most spectacular features are the military base, with its iconic, albeit completely rebuilt, Porta Praetoria (Fig. 3), and an amphitheater whose backdrop is a breathtaking Transylvanian landscape. Most of the architectural features only protrude $50-80 \mathrm{~cm}$ from the ground and have been "capped" with cement to help preserve them. Fortunately there are no environmental or human-provoked risks that endanger the site. Considering that archaeological work has been conducted nearly every year since 1977, the
Salaj County Museum constructed dormitory facilities about 30 years ago for teams of archaeologists. There are no facilities for touristic visitors to the site.

\section{CHALLENGES AND SOLUTIONS}

There are three primary concerns regarding the archaeological site of Porolissum: scientific research, upkeep and conservation, promotion and tourism. Several different stakeholders play official and unofficial roles in achieving results:

- Salaj County Government. The archaeological patrimony of Romania is controlled by the State while county or municipal administrators ultimately manage sites. Porolissum is, therefore, managed under the authority of the Salaj county government, which allocates a certain amount of funding. Much of the funding for Porolissum is channeled through the Salaj County Museum of History and Art, while some county funds are applied directly to the site. Within the county government is an officer of culture and tourism, who organizes some of the popular events staged at the site (see below). Unfortunately, the County does not always consult with the archaeologists at the Museum and, therefore, decisions are sometimes poor. The County is primarily interested in using Porolissum as a tourist attraction and, hence, viewed as a mechanism to gain revenue (i.e., very little interest in science or upkeep).

- Salaj County Museum of History and Art. As the name implies, this museum is a component of the county, although not all funding derives from the county. ${ }^{1}$ The Museum is led by a director, whilst a research staff covers each of the major fields of study from Stone and Bronze Age archaeology through modern ethnography and art. The primary duty of the Staff is to conduct research and to safeguard and investigate the historical and cultural heritage of the county. Museum staff is

1 The archaeologists are frequently involved in salvage projects, which provides the second largest amount of funding for the Museum. 


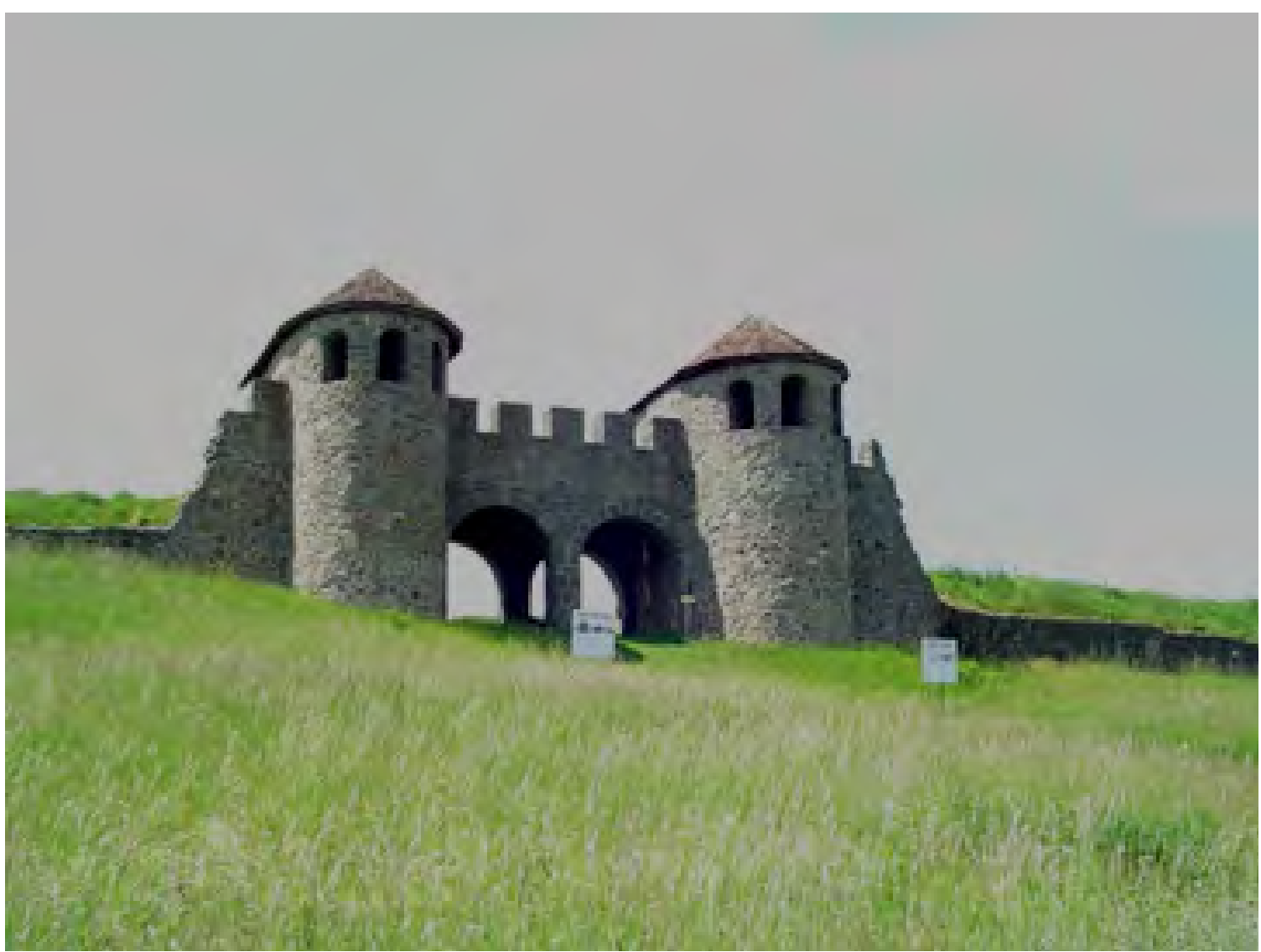

Fig. 3 Porolissum, Porta Praetoria

also called upon to develop exhibitions and engage in other museum activities. The Museum oversees all archaeological activities in Salaj County, except that Porolissum is sometimes overseen by a Staff member of the Institute of Archaeology in Cluj or Babeș-Bolyai University (see below). In terms of Porolissum, the Museum directly oversees the upkeep of the site, hiring laborers to clean the site. The Museum has a strong interest in the well-being of the site, from a scientific point of view and from the point of view of upkeep and maintenance. The Museum gains a small amount of revenue from ticket sales and public events they sponsor.

- The Institute of Archaeology of Cluj-Napoca and archaeologists based at Babeș-Bolyai University of Cluj-Napoca. Archaeologists at these institutions in Cluj-Napoca clearly have a stake in Porolissum, since this is one of the most important archaeological sites in all Romania. Many archaeologists seek to conduct research on aspects of the site, which may involve excavation or the study of material, such as coins or oil lamps from the site. Some of the senior archaeologists, however, have sought to control the scientific direction of the site. The primary interest of archaeologists from these institutions is research.

- Foreign archaeologists and students. Over the years Profs. Gudea and Matei sought collaborations with international teams. Many collaborations were short-lived; however, a small number, including the Porolissum Forum Project (Fig. 4) and the University of Cologne/ Babeș-Bolyai University Castrum Project endured for many years. In both cases, members of the foreign team not only explored the site scientifically, but developed an emotional link to the site that has led many team members to promote 


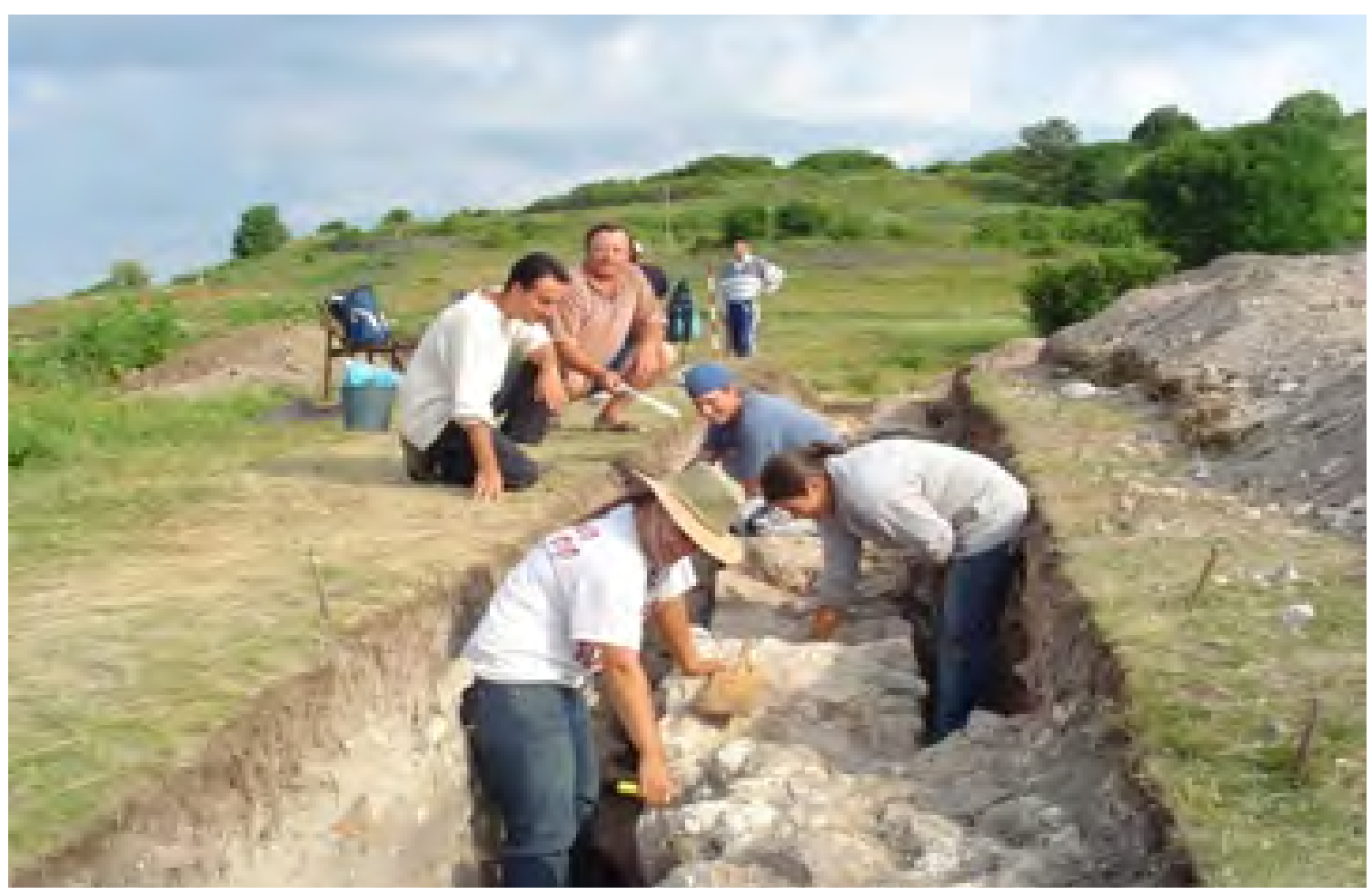

Fig. 4 Porolissum Forum Project, 2004

Porolissum to scholars and the general public in Europe and the USA. Collectively, these two teams trained about 200 western students. The main interest of the foreign teams is research; the foreign teams are interested in the well-being of the site and in attracting other scholars and tourists.

- Local business owners. Local business owners are clearly interested in economic returns from visitors to the site. A very small number of business owners give back to Porolissum, generally in the form of small donations of hundreds or, perhaps one thousand euro that are used for book publications or events at Porolissum.

In terms of scientific research, Porolissum is still largely unexplored. Many of the primary architectural features have been investigated and published to some degree; however, there are many questions, particularly regarding matters of site history and anthropology which, until now, have not been addressed adequately. Archaeological work has always involved Romanian teams, while in recent years there have been a small number of partnerships with foreign scholars. Because Porolissum is among the best preserved sites in Romania, it has been the venue of political struggles between senior scholars from the Institute of Archaeology, Babeș-Bolyai University and the Salaj County Museum. Prof. Nicolae Gudea served as scientific director of Porolissum for two decades until an agreement was made whereby he oversaw excavations in the area of the castrum and Alexandru Matei (former director of the Salaj County Museum) oversaw excavations in the municipium. With the retirement of Prof. Gudea and the death of Dr. Matei, Prof. Coriolan Opreanu (Institute of Archaeology) is the current scientific director of Porolissum. In the 1990's, after the fall of Communism, Profs. Gudea and Matei began to seek foreign collaborators. Funding from Bucharest is quite limited and economic resources from foundations are difficult to obtain. Therefore, Profs. Gudea and Matei believed that foreign archaeologists could provide valuable scientific input as well as funds for projects. In the late 1990's Matei worked with Dutch archaeologists to survey the municipium using magnetometry, while a Spanish team excavated with him for one season. In 2004, Matei struck 


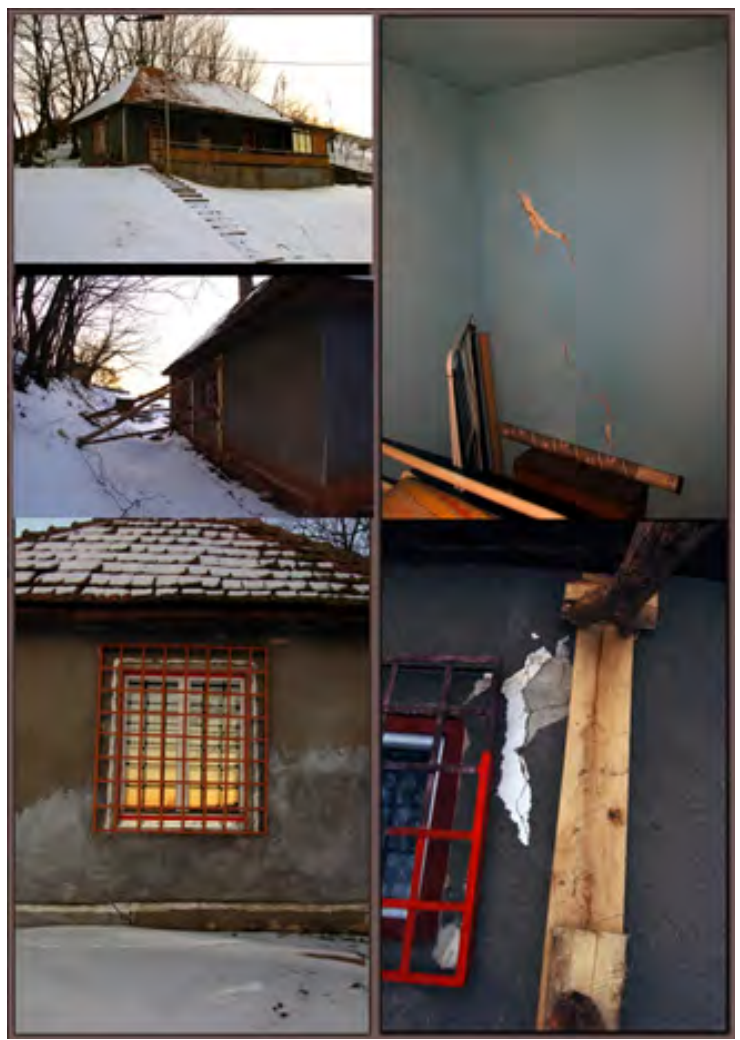

Fig. 5 Views of the on-site dormitory for archaeological teams, winter 2011

a partnership with the author of this paper, forming the Porolissum Forum Project. Prof. Gudea's most successful international collaborators hailed from University of Cologne. This team investigated a subterranean structure in the castrum, adjacent to the principia. The final year of both projects was 2011. In 2012, Prof. Opreanu was the sole explorer of the site, excavating two trenches along the north wall of the castrum and commissioning a campaign of geophysical prospection near the amphitheater and throughout the municipium. If the scientific direction of archaeological projects has often been in the hands of scholars from Cluj-Napoca, upkeep and conservation of the site has always been entirely in the hands of the Salaj County Museum. The 50+ acres of the site need to be cleared of tall grass each year; garbage is collected and minor repairs are made on standing architecture. The Museum has a small group of site curators who direct laborers that maintain the site. While the state of standing architectural features is generally stable, the re-built Porta Praetoria is deteriorating and is in need of repair. An attempt was made by a foreign member of one of the archaeological teams to gain the support of the
World Monuments Fund; however, the site was not viewed as endangered and, therefore, funding was declined. Also in a poor state is the 30-year old dormitory. Two buildings consisting of kitchens, bedrooms, a common room and a bathroom were constructed in the 1980's for archaeological teams. Basic maintenance and repairs are generally made each year by the Museum; however, settling has caused significant structural damage in one of the buildings, while time has simply left many of the rooms and facilities in a poor state (Fig. 5). The county, so far, which is ultimately responsible for financing the site, has not responded adequately.

Promotion of the site to potential visitors seems to be a key. If the state is unable to finance the upkeep of such an important archaeological site and if outside grant money is scarce, revenue generated through visitors to Porolissum may be an answer. The two primary stakeholders, namely the County Museum and Salaj County itself, have developed several initiatives to promote the site and increase the number of tourists. The initiatives generally involve some sort of spectacle.

The most popular initiative of the Salaj County Museum is Porolissum Day(s), an annual festival of one or two days that involves food, lessons in history and site tours, music, dance and reenactment groups (Figs. 6-7). A key mover of this was Alexandru Matei, director of the Museum 1985-2001 and 2009-10. Working with county authorities and a small number of reenactment groups, Matei implemented his concept for the first time in 2006. Due to a lack of interest and funds, the event was not staged for several years; however, thanks to some funds from the Museum and the generosity of the Porolissum Forum Project, an event was held in summer 2009. The County began to support this project in 2010 and it has become a steady event. The event, generally staged in late summer, takes months of planning on the part of the Museum and attracts many hundreds of visitors. Entrance fees are not collected, but some revenue is generated through the sale of food and drink as well as some merchandise. There are a number of groups dressed in costumes who perform music or dance and who demonstrate horsemanship or skills with weapons. In recent years, the culminating reenactment event is a staged battle involving dozens 


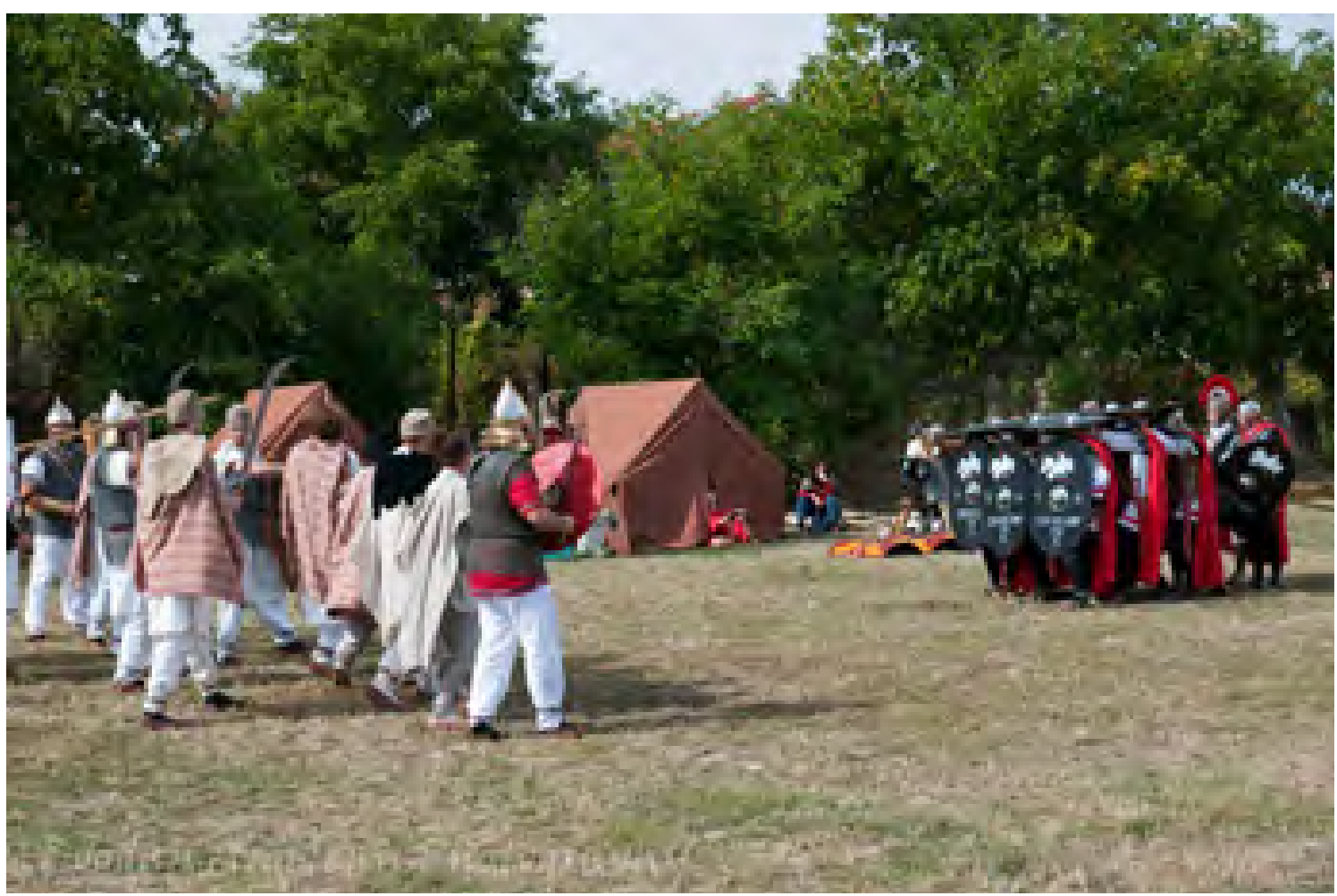

Fig. 6 Porolissum Day 2012

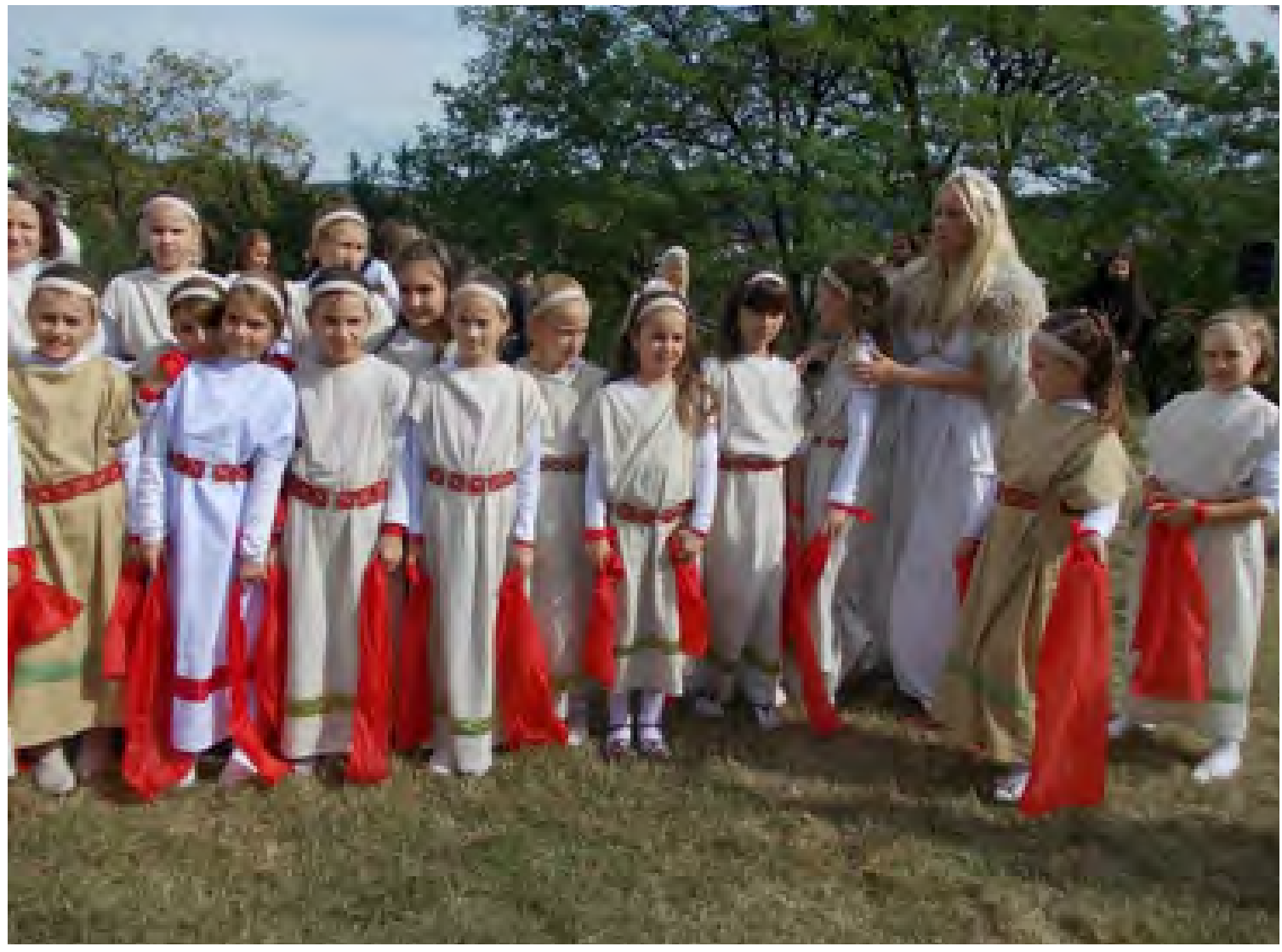

Fig. 7 Porolissum Day 2012 
of passionate reenactors. One year involved the siege of the castrum by Vandals, while last year's performance focused upon the emperor Trajan. The 2009 event concluded with the screening of "Gladiator", while the 2010 event concluded with an acoustic rock concert by local musicians.

The Museum organized a very interesting one-time event in 2010, "Archaeology and Art” (Figs. 8-9). A dozen artists from the region were invited to stay at Porolissum for four days. During this time, the artists explored the site with archaeologists and learned about the processes of excavation and discoveries of the 2010 projects. The fourth day involved an exhibition of the artists' work - photography, paintings, drawings and sculpture. While a very interesting concept and event, not many members of the public attended the exhibition.

Far more popular are music concerts and disco nights in the amphitheater, organized by the County administration (Fig. 10). Several times each summer, the County invites musical performers of various genres, from traditional folk music to chalga/manele formations, and DJ's. These events attract hundreds of visitors to the site. There is nothing particularly related to the archaeology and history of the site that accompanies these musical events; the amphitheater is simply used as a venue. Because of the nature of the music and the likely participants, alcohol and cigarette consumption is high and trash is scattered throughout and beyond the amphitheater. Cleaning crews eventually liberate the site of trash, but this is one major negative impact of such events.

Another popular "cultural" type of event that draws hundreds of people, albeit a more respectful class of person, are film screenings. Recently, the County has organized 2-3 film screenings per summer, both Romanian and foreign films. Once again, there is no direct archaeological connection to the event - the amphitheater, once again, is used as a pleasant venue on warm summer nights at Porolissum (Figs. 11-12).

All of these popular events attract visitors and some revenue is gained by the organizers; however, little is done to improve the condition of the site with these funds. Moreover, many of the visitors come strictly for the event and may not return for the simple pleasure of visiting the site. Statistics are not readily accessible; however, the num-

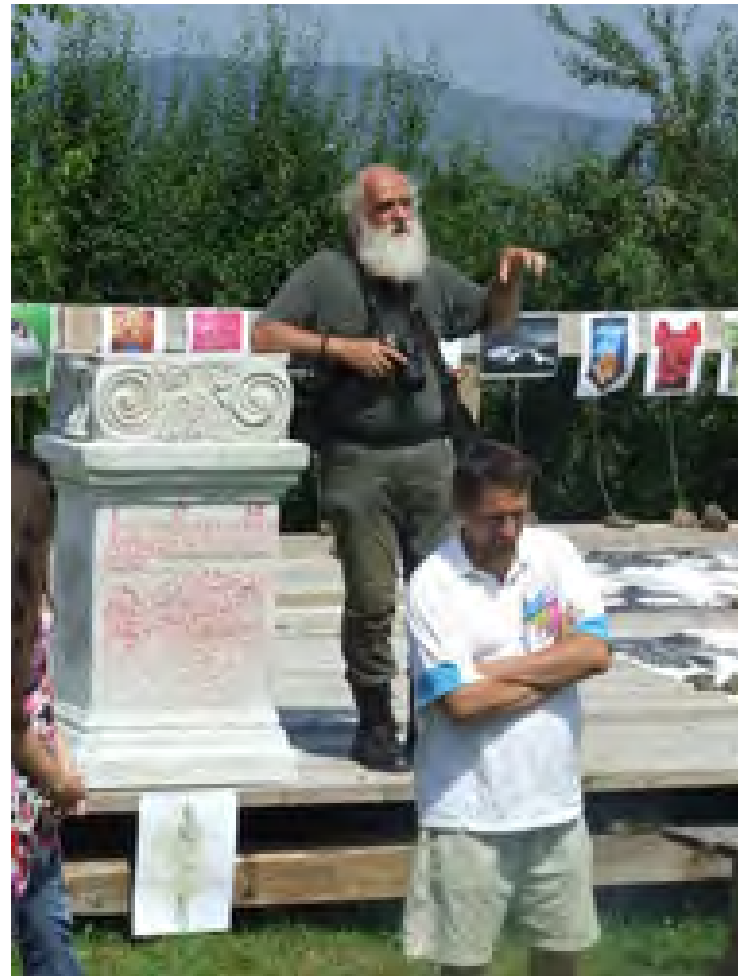

Fig. 8 Porolissum, “Archaeology and Art 2010”

ber of visitors to Porolissum who are drawn by the history and archaeology of the site is in the range of 1500-2000 per year, whilst the same number of visitors is attracted by the entertainment events.

While the total number of visitors per year is only in the low thousands, the County needs to find a creative way to facilitate visitors. Currently, there are two small wooden shacks at the entrance to the archaeological site which serve the ticket distributors and from which visitors can purchase souvenirs. There are no on site facili-

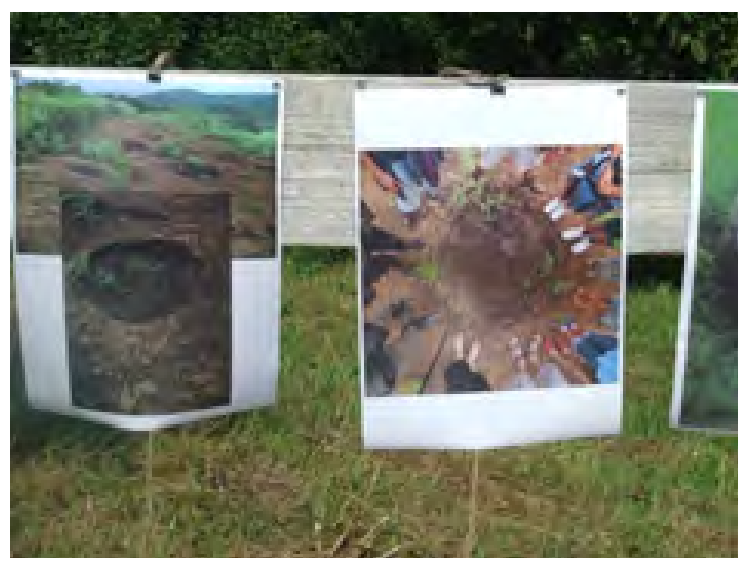

Fig. 9 Porolissum, “Archaeology and Art 2010” 


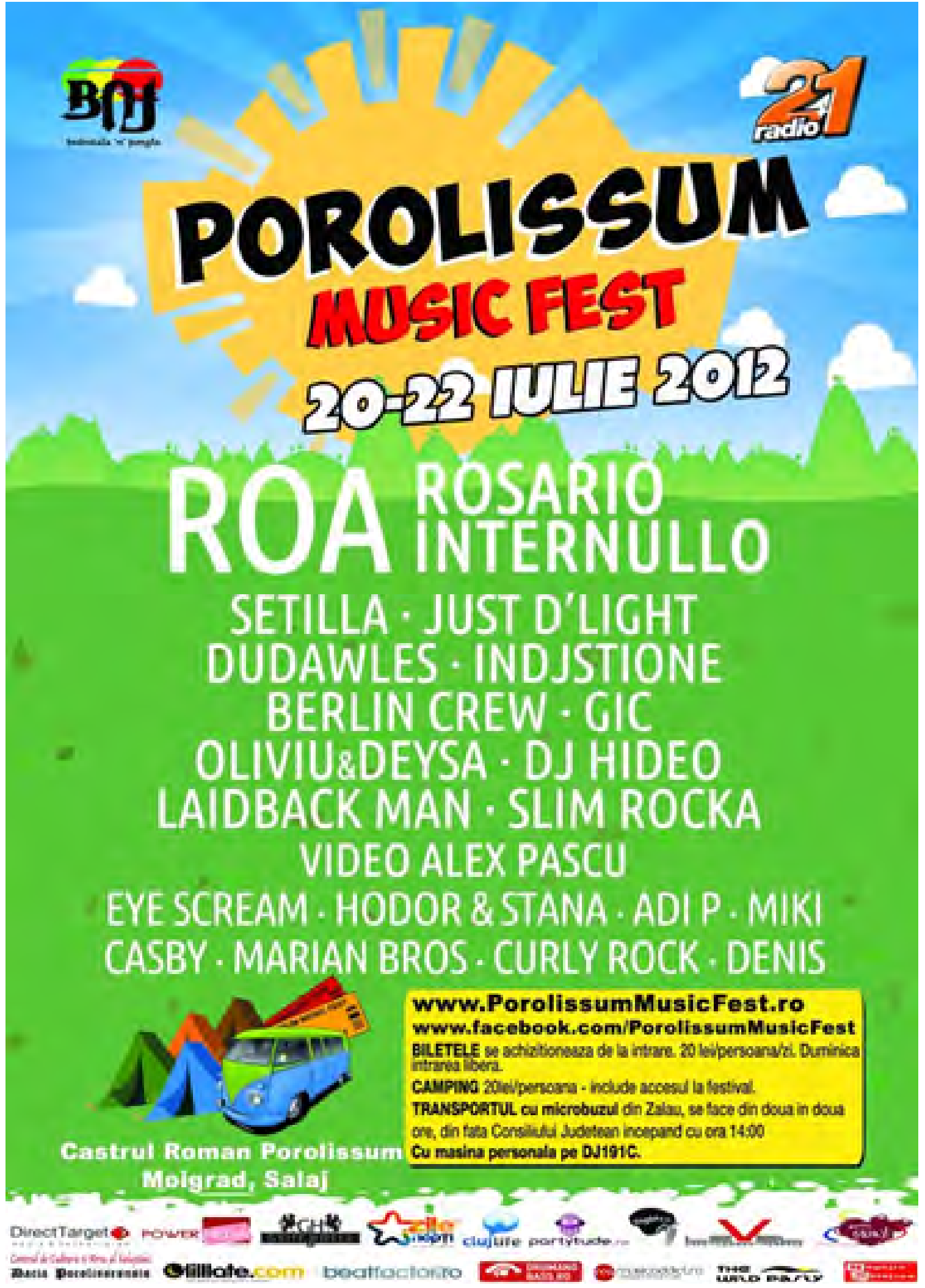

Fig. 10 Poster for a music festival at Porolissum 
ties to provide refreshments or for the biological needs of visitors. There are plans, however, by the County to pave a new road and parking area and to construct a small visitor's center. Problematically, the County does not consult with the archaeologists of the Museum who know the site.

\section{CONCLUSIONS}

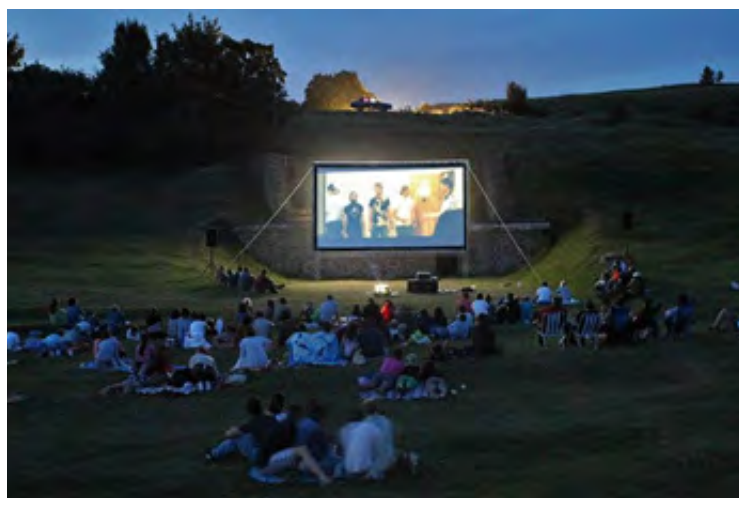

Fig. 11 Porolissum, film festival 2012

The managers of nearly all archaeological and historical sites in the world are facing many of the same challenges. In 1977, Porolissum was a traditional archaeological site frequented by archaeologists and a few visitors. By the 1980s and 90s some of the leaders began to maintain and develop the site by constructing excavation facilities, cap walls, rebuild the Porta Praetoria, and attract foreign teams of archaeologists as well as more tourists. All of the research projects and popular events have had benefits. They have attracted both archaeologists (Romania and foreign) and visitors (primarily Romanian and nearby countries); promoted education (archaeology students on projects and general public via Roman festivals/entertainment); and, established contemporary engagement with the site (art show, movies, etc.). The author of this paper has seen significant positive changes at Porolissum since his first visit in 2003, but more can be done.

The stakeholders must realize that Porolissum is not Pompeii - there will never be millions of visitors annually and revenue from ticket sales and events will never be very large. The leader(s) should have realistic expectations and make best use of their unique resources and opportunities.
Porolissum is intrinsically important and, therefore, the site requires care. Porolissum will benefit by the establishment of a clear vision and a business plan to achieve goals, improved cooperation between stakeholders, and increased support from Bucharest:

- Vision and Goals. A single individual,

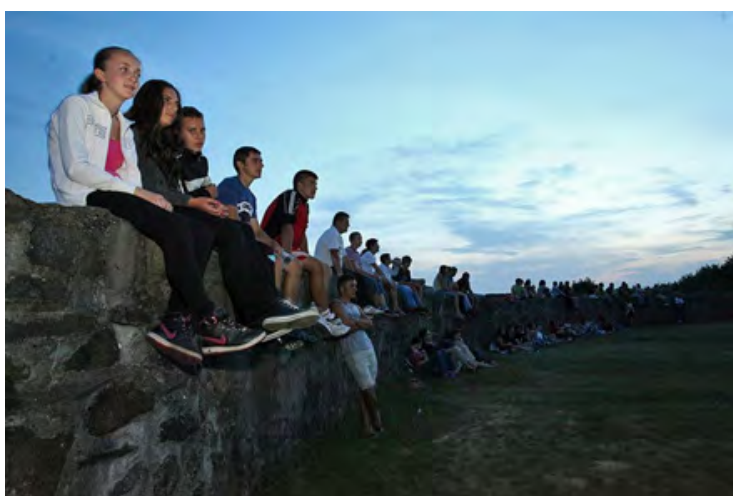

Fig. 12 Porolissum, film festival 2012

preferably a staff member of the Museum, should be appointed to oversee all aspects of Porolissum: coordination of research, caretaking and preservation, infrastructure, and public relations. This site administrator should develop a vision with immediate, middle-term and long-range goals; (s)he should develop a business plan. In developing a vision and a business plan, the site director should consult with a range of specialists - financial, preservation, archaeology, tourism. This is the way in which all successful historical sites are managed.

- Cooperation. The two primary stakeholders surrounding Porolissum are the Salaj County Government and the Salaj County Museum. Both have good ideas; however, there is little effective communication. Clearly, the Museum should act as the driving force of Porolissum as their staff possesses the most knowledge of and experience with the site (both scientific and logistical). All programs regarding the public must be coordinated and both stakeholders should be involved in making key decisions. All parties, includ- 
ing the secondary stakeholders, need to resolve differences (when they exist) and think about what is right for Porolissum. The well-being of the site should be elevated above careers and egos.

- Interest from Above. Bucharest has to invest more in the cultural patrimony of Romania. Even countries with more developed economies, such as France, rely strongly on tourism. Bucharest must learn to value historical sites as a resource and invest in maintenance, staff, and international advertising campaigns (if you build it, no one will come unless you advertise). If money is lacking, the State should work to indentify private and corporate sponsors to develop and maintain historical sites.

\section{BIBLIOGRAPHY}

\section{Bajusz, I. 1997}

Inscripţia CIL III 836 şi realitatae arheologică. Date preliminare privind amfiteatrul de la Porolissum. Civilizaţia romană în Dacia. M. Barbulescu (ed.) Cluj-Napoca, 92-101.

\section{Bajusz, I. 1999}

Propunere de reconstituire a amfiteatrul de piatră de la Porolissum. Napoca. 1880 de ani de la începtul vieţii urbane. Cluj-Napoca, 11-31.

\section{Chirilă, E. et al. 1972}

Das Römerlager von Buciumi. Beiträge zur untersuchung des Limes der Dacia Porolissensis, Cluj-Napoca.

\section{Diaconescu, A. 2004}

The towns of Roman Dacia: an overview of recent archaeological research. Roman Dacia. The Making of a Provincial Society. W.S. Hanson and I.P. Haynes (eds.). Journal of Roman Archaeology Supplemental Series 56: 87-142.

\section{Găzdac, C. 2006}

Coins from Roman Sites and Collections of Roman Coins from Romania. Vol. II. Porolissum. Mega Printing House (Cluj-Napoca).

\section{Gudea, N. 1985}

Contribuţi la istoria militară a Daciei Porolissensis I. Linie înaintată de turnuri şi fortificaţii mici de pe sectorul de nord-vest al limes-ului provinciei între castrele Bologa şi Tihau, Acta Musei Porolissensis IX: 143-218.

\section{Gudea, N. 1989}

Porolissum. Un complex daco-roman la marginea de Nord a Imperiului Roman, I. Zalău: Acta Musei Porolissensis XIII.

\section{Gudea, N. and Schüller, W. 1998}

Porolissum. Ausschnitte aus dem Leben einer dakisch-romischen Granzsiedlung aus dem Nord-Wester der Provinz Dacia Porolissensis. Amsterdam.

Gudea, N. and Tamba, G.D. 2001

Porolissum. Un complex daco-roman la marginea de Nord a Imperiului Roman, III. Despre tempul zeului Iupiter Dolichenus din Municipium Septimium. Zalău: Bibliotheca Musei Porolissensis.

Inomata, T. and Webb, R.W. (eds.) 2003

The Archaeology of Settlement Abandonment in Middle America. University of Utah Press.

\section{Landes-Gyemant, A. and Gudea, N. 2001}

Das Römerkastel von Buciumi. Vorschläge für eine grafische Wiederherstellung, Saalburg Jahrbuch 51: 127-151.

\section{Matei, A.V. 2003}

Despre castrele romane de la Porolissum. Un nou castru din tempul lui Traian descoperit la Porolissum, Acta Musei Porolissensis XXV: 277-298.

Matei, A.V. and Bajusz, I. 1997

Castrul Roman de la Romita-Certiae. Zalău: Ghid al Monumentelor din Dacia Porolissensis 4, Zalău.

\section{Petolescu, C.C. 1997}

Die Auxiliarreinheiten im römischen Dakien. Contribuţi la cunoaşterea armatei romane din provinciile dacice. N. Gudea (ed.), Cluj-Napoca, 66-141.

Pop, H. et al. 2006

Şimleu Silvanie I. Istoricul Cercetărilor. Editura 
Mega, Cluj-Napoca.

Tamba, G.D. 1997

Castrul roman de la Românaşi - Largiana. Ghid al monumentelor arheologice din Dacia Porolissensis 3 , Zalău.

Tamba, G.D. 2009

Porolissum. Asezarea civila (vici militaris) a castrului mare de la Porolissum. Ed Mega, Cluj-Napoca.

\section{REZIME}

\section{POROLISSUM: PRIMER ARHE- OLOŠKOG NASLEĐA RUMUNIJE}

Key words: Porolissum, rimski, Rumunija.

Smešten u severozapadnoj Rumuniji, rimski grad Porolissum je svrstan među najvažnije arheološke lokalitete na Balkanu. Porolissum je bio vojni centar od izuzetnog značaja, koji se razvio u omanji rimski grad, sa trgovačkim vezama širom imperije i barbarikuma. U tekstu se govori o tome kako se upravlja ovim lokalitetom, kako se on istražuje i na koje se sve načine promoviše. ${ }^{2}$

Postoje tri najvažnija faktora koji se odnose na arheološki lokalitet Porolissum: naučno istraživanje, zatim održavanje i konzervacija i najzad promocija i turizam. Nekoliko različitih elemenata igraju zvaničnu ili pak nezvaničnu ulogu u postizanju ovih rezultata:

- Uprava okruga Salaj. Arheološkim nasleđem Rumunije upravljaju država i okružna ili opštinska uprava. Tako Porolissum spada u okrilje uprave okruga Salaj, koja raspolaže određenom količinom sredstava za te svrhe. U sastavu okružne uprave je zvaničnik za kultu-

2 Ovo je rezime članka napisanog za akta simpozijuma "Archaeological Heritage - its Role in Education, Presentation and Popularization of Science," koji je Arheološki Institut Srpske Akademije Nauka organizovao na Viminacijumu u oktobru 2012. Autor ovog članka je radio kao pomoćni direktor projekta Porolissum Forum Project, od 2004. do 2010. zajedno sa Alexandru V. Matei, a u 2011. sa Robert Wanner-om i dobro je upoznat sa upravom i promocijom lokaliteta. ru i turizam koji organizuje neke od popularnih događanja koja se odvijaju na samom loklitetu. U nekoliko navrata svakog leta, okružna Uprava poziva muzičare i DJ-eve različitih muzičkih pravaca, od tradicionalne narodne muzike do najmodernije i organizuje dva do tri filmska festivala na kojima se prikazuju kako rumunski, tako i strani filmovi. Ove muzičke festivale ne prati ništa što bi stajalo u vezi sa arheologijom ili istorijom lokaliteta; amfiteatar se jednostavno koristi kao bina. Ovi događaji na lokalitet privuku na stotine posetilaca. Uprava okruga je prvenstveno zainteresovana za Porolissum kao turističku atrakciju, pa se on stoga posmatra kao mehanizam za sticanje dobiti.

- Muzej Istorije i Umetnosti okruga Salaj. Muzej čuva i istražuje istorijsko i kulturno nasleđe okruga Salaj, ali od 2010. nije odgovoran za naučnu interpretaciju Porolissum-a. Muzej direktno nadgleda održavanje Porolissum-a i najmi radnike koji su zaduženi za održavanje lokaliteta. U cilju promocije, najpopularnija inicijativa Muzeja okruga Salaj su tzv. Dani Porolissum-a, koji se svake godine održavaju tokom jednog ili dva dana, a obuhvataju hranu, predavanja o istoriji i obilaske lokaliteta, muziku, ples i grupe kostimirane u istorijske kostime. Jedan od najzanimljivijih jednokratnih događaja iz 2010. godine, "Arheologija i Umetnost”, na lokalitet je, u period od četiri dana, doveo na desetine umetnika iz ove oblasti. Umetnici su obišli lokalitet sa arheolozima i saznali dosta toga o iskopavanjima i otkrićima iz 2010.; vrhunac ovog događaja je bila izložba sa radovima ovih umetnika. Muzej ima manju dobit od prodaje ulaznica i javnih događaja koje sponzoriše.

- Arheološki Institut Cluj-Napoca i arheolozi sa Babeș-Bolyai Univerziteta u Cluj-Napoca. Arheolozi iz ovih institucija u Cluj-Napoca imaju najvažniju ulogu u Porolissum-u, s obzirom da je on jedan od najvažnijih lokaliteta u celoj Rumuniji. Mnogi arheolozi žele da rukovode iskopavanjima na ovom lokalitetu ili pak 
da proučavaju nalaze, npr. novčiće ili žiške. Izvestan broj starijih arheologa se izborio da vrši kontorlu nad istraživanjima na lokalitetu. ${ }^{3}$ Jedini interes arheologa iz ovih institucija jeste istraživanje.

Rukovodioci gotovo svih arheoloških ili istorijskih lokaliteta širom sveta suočavaju se sa mnogim od ovih izazova. Tokom 1977, Porolissum je predstavljao tradicionalan arheološki lokalitet koji su brojni arheolozi često posećivali, kao i manji broj posetilaca. Tokom 80-tih i 90-tih, neki od tadašnjih rukovodilaca su otpočeli sa održavanjem i razvojem lokaliteta tako što su izgradili prostorije za arheologe i za nalaze, rekonstruisali zidine, rekonstruisali porta praetoria-ju i na lokalitet privukli inostrane arheološke ekipe, ali i veći broj turista. Od toga su korist imali istraživački projekti, ali i popularni događaji. Oni su animirali kako arheologe (rumunske i inostrane) tako i posetioce (prvenstveno rumunske i iz susednih zemalja); promovisali su obrazovanje (studenti arheologije na projektima i široka publika - posetioci rimskih festivala/zabave). Takođe su uspostavili angažmane vezane za lokalitet (umetničke programe, filmove itd.). Autor ovog članka je uočio mnoge pozitivne promene u Porolissum-u od 2003., kada je prvi put posetio lokalitet, iako još mnogo toga može biti urađeno.

Popularni događaju privlače posetioce, a izvesnu dobit imaju i organizatori; međutim, iz ovog fonda se malo toga ulaže u poboljšanje samog lokaliteta. Štaviše, mnogi posetioci dolaze na lokalitet isključivo zbog pojedinih događaja i ne vraćaju se da bi uživali u poseti samom lokalitetu kao takvom. Iako se ukupan godišnji broj psetilaca izražava u samo nekoliko hiljada, postoji potreba za smeštajem posetilaca. Trenutno postoje dve manje drvene kolibe na ulazu u arheološki lokalitet, koje služe za prodaju ulaznica i u kojima posetioci mogu da kupe suvenire. Ne postoje prostorije u kojima bi se prodavala osveženja, niti za biološke potrebe posetilaca.

Čelnici treba da shvate da Porolissum nije Pompeji - on nikada neće privući na milone posetilaca na godišnjem nivou, niti će dobiti od prodaje ulaznica ili povremenih događaja biti jako visoke. Rukovodioc(i) treba da imaju realna očekivanja i da na najbolji način iskoriste svoj jedinstveni potencijal i mogućnosti. Porolissum je suštinski

3 Coriolan Opreanu (Arheološki institut Cluj-Napoca) je od 2010. naučni direktor i od 2012. samostalni istraživač ovog lokaliteta. važan i zbog toga ga je potrebno čuvati. Porolissum će ići u pozitivnom pravcu ako se uspostave jasna vizija i plan kako da se stigne do ciljeva, ako se poboljša saradnja među čelnicima i ako dobije veću podršku iz Bukurešta:

- Vizija i ciljevi. Pojedinac, izabran po mogućstvu među osobljem muzeja, treba da bude imenovan da sagleda sve aspekte Porolissum-a: rukovođenje istraživanjem, zaštita i konzervacija, infrastruktura i odnosi sa javnošću. Rukovodilac lokaliteta treba da razvije plan koji sadrži trenutne, kratkoročne i dugoročne ciljeve; takav pojedinac treba da razvije poslovni plan. Tokom razrađivanja vizije i poslovnog plana, rukovodilac lokaliteta treba da se savetuje sa nizom stručnjaka - finansijskih, konzervatorskih, arheoloških i turističkih. Na ovaj način se upravlja svim uspešnim arheološkim lokalitetima.

- Saradnja. Dva najvažnija čelnika u okolini Porolissum-a su Uprava okruga Salaj i Muzej Istorije i Umetnosti okruga Salaj. Oba imaju dobre ideje; međutim, malo je efikasne komunikacije među njima. Jasno je da Muzej treba da predstavlja rukovodeću snagu Porolissum-a, s obzirom da njegovo osoblje ima najveće znanje o lokalitetu i najviše iskustva sa njim (kako naučno, tako i logističko). Svi programi koji podrazumevaju učešće široke publike treba da budu usklađeni i oba čelnika treba da budu uključena u donošenje ključnih odluka. Svi činioci, uključujući i drugostepene čelnike, treba da prevaziđu razlike (kada ih ima) i da shvate šta je ispravno za Porolissum. Dobrobit lokaliteta treba da se izdigne iznad pojedinačnih karijera $i$ ega.

- Zainteresovanost iz centra. Bukurešt treba više da ulaže u kulturno nasleđe Rumunije. Čak i zemlje sa mnogo razvijenijom ekonomijom, kao npr. Francuska, mnogo polažu na turizam. Bukurešt treba da počne da ceni istorijske lokalitete kao potencijale i da ulaže u održavanje, osoblje i međunarodne reklamne kampanje. Ukoliko nedostaje novac, država mora da nađe privatne i korporacijske sponzore da bi razvijala i održavala istorijske lokalitete. 